\title{
AUTHOR INDEX VOLUME 3 (1985)
}

(The issue number is given in front of the page numbers)

Bellardo, T., Accreditation for all the information professions (Short Communication)

(2) $149-150$

Boras, D., see M. Tudman

Borko, H., Artificial intelligence and expert systems research and their possible impact on information science education

(4) 291-306

(2) $103-114$

Cronin, B., see F. Gibb

(4) $307-312$

Davinson, D., and N. Roberts, The overlooked factor: the resource issue as the shaper of library and information school curricula

(1) $29-37$

Dosa, M.L., Education for new professional roles in the information society

(3) $203-217$

Ford, N., Styles and strategies of processing information: implications for professional education

(2) $115-132$

Gibb, F. and B. Cronin, Prototype identification using a knowledgebase management system (Short Communication)

(4) $307-312$

Kajberg, L., Sticking in the watershed for 12 years: towards restructured librarianship and information science programmes in Denmark

(3) $219-236$

Koenig, M.E.D., Education for serials librarianship: what are the not so obvious basic components?

Kularatne, E.D.T., Library education and training for sub-professionals in developing countries

Maniez, J., Outline of a methodology for training in librarianship (Short Communication)

(1) $51-54$

Milas, M., see M. Tudman

(4) 291-306

Nzotta, B.C., Education and training of library personnel in Nigeria: some challenges for the next decade

(1) 39- 49

Roberts, N., see D. Davinson

(1) $29-37$

Saunders, W.L., Library and information science education for Yugoslavia: an external view of needs and problems

(4) $275-282$

Schwarz, S., Education for research in library and information science: a basis for policy analysis in the Nordic countries

(2) $83-102$

Tenopir, C., Information science education in the United States: characteristics and curricula

(1) 3- 28 
Tudman, M., M. Milas, N. Tudor-Šlović and D. Boras, Bibliometric analysis of master theses in information sciences (Postgraduate studies in librarianship, archivistics, museology and information science, 1961 -1984, Zagreb, Yugoslavia)

(4) 291-306

Tudor-Šilović, N., see M. Tudman

(4) 291-306

Vogel, E., The Konstanz conception for a postgraduate programme in information science: information counselling and information management

(2) $133-148$ 